\title{
The Existence of Customary Law and Islamic Law in the Optics of the Indonesian Legal System
}

\author{
Martitah $^{1}$, Slamet Sumarto ${ }^{2}$ and Arif Hidayat ${ }^{3}$ \\ \{martitahlatif@mail.unnes.ac.id ${ }^{1}$, met_pkn@mail.unnes.ac.id ${ }^{2}$ and arifardat@gmail.com ${ }^{3}$ \} \\ ${ }^{1,3}$ Faculty of Law, Universitas Negeri Semarang, Indonesia \\ ${ }^{2}$ Faculty of Social Science, Universitas Negeri Semarang, Indonesia
}

\begin{abstract}
This article aims to describe the existence of Customary law and Islamic law in the legal system in Indonesia. The complexity of the law in Indonesia is colored by legal pluralism, which in addition to national law, also applies customary law and Islamic law. In its development, national law influenced by western law began to eliminate the existence of unwritten customary law. However, this is different from the existence of Islamic law, which gets space and influences the development of national law, especially in economic activities. Some of the laws and regulations influenced by Islamic law include Law on the Implementation of Hajj, management of zakat, waqf, Application of Privileges in Aceh, and Special Autonomy in Aceh, and religious courts. Thus, apart from customary law, the principle of sharia has become one of the sources for the formation of national law.
\end{abstract}

Keywords: Customary Law, Islamic Law, Legal System, Indonesia

\section{Introduction}

The legal system is a unity of legal regulations consisting of parts (law) that have a relationship (interaction) with each other, which is arranged in such a way according to its principles, which serves to achieve legal objectives. Each part does not stand alone, but is bound together. The importance of each part lies in the bonding of the system, in a unified and systematic relationship with other legal regulations. Therefore, in a good legal system there should be no conflict between the parts. If a conflict or construct occurs, the system itself resolves it. According to Peter de Cruz, the legal system is the operation of a set of legal institutions, procedures and regulations.[1] While in the broadest sense it is defined as the same Juristic philosophy and technique used by a number of countries which generally have a common legal system. This legal system in its broadest sense describes a parent legal family, such as the legal family of Civil law, Common law, Socialist law and Islamic law.

Thought about the legal system is not free from criticism and has been implemented in various ways even though there is no consensus among observers about whether this concept is purely heuristic, fundamental and scientific or less useful theoretically and descriptively. Even when the concept is used, there are no classification criteria. For example Zweigert and Kotz prefer only juristics, while Glasson and Sarfatti focus on the historical origin of a system as a distinguishing or identifying feature. Likewise, there is no agreement regarding the grouping of various legal systems. [2]

There are many criteria that have been proposed as a means to classify certain legal systems, ranging from taste and language (sauser-hall), culture (Schnitzer), substance (substantive content of law by 
Arminjo, Nolde and Wolf), ideology, philosophy, conception of justice and legal techniques (David), historical origins (Glasson and Sarfatti) and yuristic styles (Zweigert and Kotz). [3] However, of the many existing criteria, Peter de Cruz recommends reviewing the approach of Zweigert and Kotz on the condition that prominent principles must be applied. The Yuristic style created by Zweigert and Kotz is a crucial test tool that determines the classification of a legal system, which can be ascertained through; (a) the historical background and development of the system; (b) characteristics of the modes of thought; (c) different institutions; (d) the types of sources he acknowledges and the treatment of all of these; and (e) its ideology. Broadly speaking, known several legal systems adopted in the countries of the world include the legal system of Continental Europe, Common Law, Anglo Saxon and Islamic Law Systems, legal systems of eastern bloc countries (socialists) and Adat Law System.

\subsection{Civil Law System of Europe (civil law)}

Civil Law is a legal system that develops on mainland Europe and is interpreted in the same way as Roman law. Roman law is said because this legal system originated from the codification of the laws that prevailed in the Roman Empire during the reign of Emperor Justinian 5th century (527-565 AD). This codification of law is a collection of various legal norms that existed before Justinian's time called Corpus Juris Civilis (codified law). Corpus Juris Civilis was used as the basic principle in the formulation and codification of law in mainland European countries such as Germany, the Netherlands, France, Italy, Latin America, Asia (including Indonesia during the Dutch colonial period).[4]

This system must be codified every law as the basis for the enactment of law in a country. The main principle of this system is that the law obtains binding power because it is in the form of a law that is systematically arranged in codification. Legal certainty which is the purpose of law. Legal certainty can be realized if all human behavior in life association is regulated by written regulations, (for example the Law). Even in this system it is said "there are no laws other than laws", so the law is identified by law.

This legal system allows the settlement of all problems or cases easily because it is based on written laws/laws, and is more able to guarantee legal certainty. But what about the problems/cases that are not contained in the Law, according to the development of the community, this makes an obstacle in solving these cases. The judge is not free in creating a new law because the judge only has the role of establishing and interpreting existing regulations based on the authority he has.

\subsection{Anglo Saxon Law System}

Anglo Saxon legal system is a legal system based on juriprudensi, namely the decisions of previous judges which later became the basis of the decisions of subsequent judges. Anglo Saxon systems tend to prioritize customary law, laws that run dynamically in line with the dynamics of society.[5] The establishment of law through a judicial institution with a judicial system and is considered better so that the law is always in line with the sense of justice and benefit that is felt by the community in reality in this legal system the role given to a judge is very broad.

The judge functions not only as the party whose task is to set and interpret legal regulations but also as a party that plays a role in shaping the entire life system of the community. In addition, it can create a new law that is used by other judges to resolve similar cases.

This legal system developed and applies to the former British colonies but is still influenced by the social systems of these countries. This system is more likely to adjust to the development of the times and society, because the laws that are applied are unwritten laws, but for legal matters, they cannot be guaranteed.

\subsection{Adat Law System}


The Legal System for the first time used by Christian Snouck Hurgronje[6] as a term for Indonesian codified people's law. Adat law is a law that lives and develops in the community for a long time based on the values that live in the community both original values and or mixed from those that come from outside and only applies to the community. This adat law is applied to create a balance in the community itself, between individuals, between communities, also towards nature, then customary law is enforced. Generally, sources of customary law are from unwritten legal regulations that grow and develop and are maintained based on the legal awareness of the community. Traditional legal nature with the origin of the will of his ancestors. Adat law changes because of the changing effects of social events and circumstances. Because of its volatility and readiness to adapt to the development of social situations, its elastic adat law. Because the source is not written, adat law is not rigid and easy to adjust.

\subsection{Islamic Law System}

The Islamic legal system adheres to the beliefs and teachings of Islam with individualized inner faith. Countries that embrace the Islamic legal system in the state carry out its legal regulations in accordance with a sense of justice based on the laws derived from the Qur'an. From the description above it is clear that in countries adhering to the principles of Islamic law, Islam has a profound effect on the way of state formation and the way of state and community for citizens and rulers. So what legal system is used in Indonesia? Interestingly, Indonesia does not use one of the above systems but uses 3 (three) systems as well as developing and living in Indonesian society in harmony, namely the legal system of Continental Europe (civil law) reflected in public and private law, Adat law systems and Islamic legal systems.

\section{Result and Discussion}

\subsection{The Complexity of the Legal System in Indonesia}

The legal system in Indonesia is influenced by a legal system originating from mainland Europe (continental Europe) because of a Dutch colonial heritage. This is proven up to now and still influences the drafting of laws in Indonesia. BurgerlijkeWetboek(BW) or Civil Code, Wetboek van Straftrechts (WvS) or Criminal Law, Wetboek Van Kopenhandel $(W v K)$ or the Commercial Code, and HerzienInlandschReglement (HIR) or Law The events in the Civil and Criminal Trial are still some of the Dutch laws that still apply in Indonesia to this day.

In addition, adat law also applies as an original law that grows and develops from the habits of the community which greatly influences the process of law enforcement in Indonesia, and this customary law is very diverse in Indonesia, so that in general implementation it will face obstacles but is efficient enough to local people who enforce it. Even if calculated, more Adat law is still valid than state law. Cornelis van Vollenhoven was the first to launch the idea of sharing adat law. According to him the area in the archipelago according to customary law can be divided into the following 23 adat environments: Aceh, Gayo and Batak, Nias and its surroundings, Minangkabau, Mentawai, South Sumatra, Enggano, Melayu, Bangka and Belitung, Kalimantan (Dayak), Sangihe-Talaud, Gorontalo, Toraja, South Sulawesi (Bugis / Makassar), North Maluku, Maluku Ambon, Southeast Maluku, Papua, Nusa Tenggara and Timor, Bali and Lombok, Java and Madura (Coastal Java), Java Mataraman, and West Java (Sunda), while according to Gerzt Americans state that Indonesian society has 350 cultures, 250 languages and all beliefs and religions in the world are in Indonesia.[7]

Islamic law is a part that also affects law in Indonesia, because the majority of religions in Indonesia are Islam, which allows Islamic law to be an important and influential part of law in Indonesia. Proven regulations regarding the Hajj Law, Sharia Banking Law and Compilation of Islamic Law and this proves that the Indonesian state does not give up responsibility for religious affairs with state / government 
affairs. So that it can be said that Indonesian law is influenced by the colors of contemporary law, customary law and Islamic law which in fact each has a large influence in the legal system in Indonesia.

The effect of the civil law legal system as a system that guarantees legal certainty because it is done based on written regulations, allows settlement to have a frame that points to certainty, but this is also not profitable because it tends to have problems when dealing with community development issues that are increasingly compound in various ways and quantity and quality of increasingly developing problems that may not yet be contained in a written regulation but do not open up space to be able to explore and find out more about how to solve a legal problem.

Adat law as the original law of the Indonesian people is also a very important part that influences the legal system in Indonesia, because it is proven, without written, from the habits that arise in the community, then forms a living law and the person manages to maintain balance among individuals in society but also maintain balance with nature, even if only for local people.

The majority of the followers of Islam in Indonesia also allows Islamic law to influence the legal system in Indonesia, therefore there are rules that are specifically related to Islamic law and this proves that Indonesia is not a country that tries to separate itself from state affairs with religious affairs.

All existing legal systems are very influential in the legal system in Indonesia, which is a problem, whether we are able to create and combine the overall advantages of each legal system to be implemented equitably in this country. Therefore, there needs to be synchronization between stakeholders in this case the law maker itself, law enforcement, service personnel, along with the community so that they can form an integrated regulation, which contains positive values of existing legal systems and will produce a system good law. If this synchronization can create a whole in the legal system in Indonesia, the most important concern is how the quality of stakeholders in the legal system itself, if carried out in accordance with functions and roles responsibly, will greatly support the process of the legal system. Indonesia.

\subsection{The Position of Adat Law in Indonesia}

The existence of Adat law as living law the Indonesian people are increasingly marginalized.[8] Adat law which was originally to be law that life and develop and be able to provide solutions in a variety of life-related problems Indonesian society, its existence is increasingly missing . At present, if we look at the empirical facts, we can find a variety of problems faced by indigenous peoples of Indonesia when adat law deals with positive law. For example, when the traditional rights of the community deal with the interests of investors through the means of state law.[9] Development of the Indonesian Legal System which tends to prefer the legal system western civil law and common law model Indonesian law and politics that led to the codification and unification of law, accelerating the loss of the existence of adat law institutions.

More further loss of adat law existence as one of the sources of law in Indonesia, one of which the cause is due to the assumption that adat law is very traditional and unable to reach the times. The implications of Indonesian legal politics can be seen also in solving problems in the community that often override the binding of adat law, even though it is actually more relevant. For example, the number of horizontal conflicts, between indigenous peoples in one area, should be resolved through the role of institutions for resolving indigenous peoples.[10] A crucial problem that arises in daily life is the difference in perception between land tenure by the community based on communal rights and public interests which is a burden and obligation of the state.[11] Another example is the idea that the basis is worthy of an action extended to the domain of customary law.[12]

Eventhough, the journey of the history of the rule of law in Indonesia has been noted that many experts actually learn that adat law as a law that living in Indonesia society. Van Vollenhoven for example, stated that if "someone wants to get knowledge and information about the law that lives on this earth, precisely because of the diversity of its forms in the past and present, then the whole rule of the Dutch East Indies (Indonesia) is a source that is never dry to learn. This statement contains the recognition 
that legal pluralism in the indigenous environment is unique, interesting and characteristic of Indonesian society. Kusni Sulang (Member of the Palangka Raya Dayak Culture Institute) even emphasized that pluralism of customary law is a blessing. [13]

Pluralism of law able to be a unifier, a solution sump creates tranquility right in the association of community life. Until now, customary law pluralism in Indonesia that has grown dynamically follows the development of its society while remaining dependent on the characteristics of indigenous peoples and participatory coschmish mindsets attracted the interest of experts from around the world to become the object of research. Just a reminder, currently related to the settlement of disputes both civil and criminal developing methods or approaches known as restorative approaches ( restorative approach ) [14], which is similar to the participerend coschmish mindset adopted by indigenous peoples. Implementation of recovery of equilibrium based on participerend mindset coschmish , incarnated in several ceremonies, taboos or rites ( rites de passage ). [15]

This fact shows that the conceptions and patterns of thinking of adat are not only still relevant, but are an inspiration for other countries to develop laws to fulfill the sense of justice of the people. Indigenous peoples have the same pattern in resolving conflicts in society, namely controlling life in society and imposing sanctions if violated so that recovery becomes very effective.[16] Another example, Utrecht University seeks to encourage the use of a consensus agreement model of the Malay indigenous community in resolving the problems that occur. In Indigenous society, dispute resolution through deliberation is a law that lives and is known in almost every legal circle ( rechtskring ). Dispute resolution through deliberation always involves the head of the people (adat leader), both in preventing legal violations (preventieve) rechtszorg ) and restore law ( rechtsherstel ).[17] On the contrary, Indonesia enacted Law Number 30 of 1999 concerning Arbitration and Alternative Dispute Resolution as an out-ofcourt settlement option, which was clearly inspired by the development of dispute resolution in the country with a common law system.

Furthermore, it can be seen that in the context of the codification and unification of law in Indonesia, various laws and regulations refer to the common law, civil law and sharia legal systems.The full acceptance of other legal systems in the formation of legislation in Indonesia in its implementation sometimes creates clashes with a sense of justice in Indonesia. A concrete example, the field of economic law, especially the capital market, for example, develops many types of nameless agreements such as collective investment contracts, trustee agreements, brokerage agreements, and derivative transactions. Especially for the practice of derivative transactions, the court still classifies derivative transactions in the capital market as a chancy agreement based on Article 1774 of the Civil Code.

This erroneous view of derivative transactions can be seen from derivative cases that occurred in the banking world between Bank Niaga and Dharmala Agrifood, Bank Niaga and Suryamas Duta Makmur, Mayora Indah and Bankers Trust, Credit Lyonnais Indonesia and PT Nugrasentana. The court considers that deriva tif transactions are considered not to fulfill the halal causal as one of the legal conditions of the agreement as stipulated in Article 1320 of the Civil Code. The example of this case proves that the acceptance of a particular legal system is sometimes difficult to apply in certain societies.

Considering that Adat law is a law that reflects the personality and soul of the nation, it is believed that some of the adat law institutions are certainly still relevant as material in forming the Indonesian legal system.[18] Adat law that can no longer be maintained will be quiet over time, in accordance with the nature of adat law which is flexible and dynamic (not static). Savigny as quoted by Soepomo asserted that adat Law is a living law, because it is the manifestation of a real legal feeling from the people. As per its own nature, adat law continues to grow and develop like life itself. In line with Savigny, van Vollenhoven said that "adat law at a time when it has been somewhat different in content, adat law shows progress". Furthermore, he stressed that "adat law developed and progressed, adat decisions gave rise to adat law". Given the adat law as the crystallization of Indonesian culture, researchers believe that an effort is needed to revitalize Adat law, and make it part of the source of national law formation. Regarding the establishment of national law, Mochtar Kusumaatmadja added that the law must be sensitive to the development of society and that the law must be adjusted and adapted to the situation. Some of the 
thoughts contained in the living law theory, including stating that in a process of forming legislation it is absolutely necessary to pay attention to legal values and norms that live and apply in society. If the enactment of a law contradicts the legal values and norms that live and apply in its society, certainly there will be rejection. In the context of Indonesia, living law of Indonesian society is Adat law. Adat law can also be used as a source of law by a judge if the law orders it.[19] Adat Law is a law that is not codified among foreign Indonesian and Eastern nations (including Chinese and Arabic).

\subsection{The Ambiguity of Recognition of Adat Law in Indonesia}

The Dutch Colonial Government recognized Adat law officially as Indonesian original law and Paralleled European law through Article 131 paragraph (6) IS which states "Indonesian law is a positive law for the Indonesian people". Definition of national law Indonesia in this article is adat law. Article 131 paragraph (6) of this is a legal basis for the recognition of the Dutch East Indies Government against adat law and at the same time recognition of customary law as positive law for the Indonesian people. With the recognition of adat law as positive law then during the Dutch East Indies Government there were two systems applicable law, namely the Dutch legal system for Europeans and for foreigners and Indonesians who are submitting themselves European law applies (Article 131 paragraph (2) IS) and customary law for the Indonesian people and foreigners who are foreign in Indonesia (Article 136 paragraph (6) IS).PostIndependence, the treatment of the first unwritten law is only explained or included in the General Explanation of the 1945 Constitution which states that I "... The Constitution is a written basic law, currently in law beside it the Constitution also applies the basic law it is not written, the basicrules that arise and are maintained within practice of state administration even though it is not written ". In Article 18B Paragraph (2) of the 1945 Constitution Amendment states "The State recognizes and respects the elders of the customary law and their traditional rights insofar as they are alive and in accordance with the development of society and the principles of the Unitary State of the Republic of Indonesia. "According to this article the recognized customary law is customary law that is still clearly alive, clearly the material and scope of the indigenous people.

The provisions of Article 18B paragraph (2) above can be understood that the 1945 Constitution prioritizes written laws rather than unwritten. The meaning is that the confession is against adat law that is still alive within the community in an area must be done with a law (written) and in line with the principle of the Unitary Republic of Indonesia. Furthermore, in providing an interpretation of these provisions, JimlyAsshiddiqie stated that it was necessary to pay attention to the following matters regarding the recognition of adat law:

1. To the existence of a customary law community with their traditional rights

2. The existence that is recognized is the existence of indigenous peoples' units. This means that recognition is given to one by one from these units and therefore the customary law community must be certain

3. The customary law community is indeed alive (still alive)

4. In certain environments too

5. Recognition and respect are given regardless of the feasibility measures for humanity in accordance with the level of development of the nation's existence

6. Such recognition must not reduce the meaning of the unity of the Republic of Indonesia

While to analyze the position customary law in the legal system should be considered one of the natural schools of law, namely, Sociological Jurisprudence delivered by Eugen Ehrlich . The basic concept of Ehrlich's thinking about law is what is called living law. Good and effective positive law is a law that is in accordance with the living law of the community that reflects the values that live in it.

Ehrlich's message to lawmakers was in making the law should pay attention to what lives in society. It is a fact and it cannot be denied that the adat law that applies in Indonesia in general and the Province of 
Aceh in particular is the law which is in accordance with the values that live in the community. Therefore, for customaryadat law to be effective in the community, in the formation of laws and Qanun in Aceh, people's representatives who sit in the legislative body must be able to explore and must accommodate legal awareness that lives in the community. Community legal awareness that has been formalized in both the law and qanun will be used as a basis for maintaining order and harmony in the life of the community.

\subsection{The Adat Legal Position in Jurisprudential Development}

In adat law, jurisprudence law, besides being a decision court that has become permanent the field of customary law, is also a means fostering adat law, according to ideals law, as well as from jurisprudence from period of time can be tracked developments in adat law, both the still local or already applies nationally. The developments adat law through jurisprudence will give knowledge of shifting and the growth of adat law, weakening local customary law and the strengthening of adat law which then becomes and binding nationally. Development of adat law through jurisprudence can tracked in several ways including:

1. Principles of Adat Law.

Customary law, among others, rests on the principle: harmonious, appropriate, laras, this is confirmed in the Supreme Court-RI jurisprudence Number: 3328 / Pdt / 1984 dated 29 April 1986. In the Supreme Court Decision No. 2898 K / Pdt / 1989 dated 19 November 1989, based on customary disputes which were held at the Kefamenanu Court, East Nusa Tenggara, the Supreme Court asserted: "In the face of civil claim cases the fondamentum petendi and petitum are based on violations of customary law and confirmation of customary sanctions; If in the trial the plaintiff can prove the argument of the claim, the judge must apply the customary law regarding the article which is still valid in the area concerned, after hearing the local customary Elder ". The next legal method: "Settlement of violations of adat law, besides through a civil suit above, it can also be taken through criminal prosecution ig article 5 (3) b of the Act No. 1 Drt / 1951 ".

2. Strengthening of Core Family Position (Gezin)

Indigenous people in Indonesia consist of groups of patrilineal communities, groups of matrilineal communities and groups of parental (bilateral).In its development it turned out to be stronger and he acknowledged a shift in the family system in matrilineal indigenous communities and matrilineal indigenous people towards the parental or bilateral system. Jurisprudence dated January 17, 1959b Number 320K / Sip / 1958 as follows:

a) The wife can inherit the livelihood of the deceased husband;

b) Children who are not yet mature are nurtured and are under the control of the mother;

c) Because the child is under the mother's control, the child's wealth is controlled and managed by the mother.

d) Position with men and women

Strengthening Protection for Women in Inheritance Law:

1) Position of Girls in Law of inheritance

Originally according to adat law in patrilineal society, girls were not heirs. But in its development recognized by jurisprudence stated that girls as the heir of his deceased parents.

2) Position of Widows in Law of Inheritance

The initial development of a widow is not an heir, in reality then the widow becomes suffering after the death of her husband, then the practice of giving a gift by a husband to his wife arises to protect and maintain a socio-economic life after the death of her husband, such practices are increasingly institutionalized. The next development of customary law is, widows as heirs together with the children of the deceased husband.Then the widow as the heir has the same position as the heir of the child. Further development is the widow as the heir of the primacy group, which closes other heirs. 
Jurisprudence Decision MA No. 387K / Sip / 1956 dated October 29, 1958, Widows can continue to control the property until they die or remarry. The climax is the Supreme Court Jurisprudence No. 3190K / Pdt / '985, dated October 26, 1987, the widow has inheritance rights from her husband's inheritance, and her rights are equal to her biological child, if she does not have children, she becomes a barrier to her husband's heirs, against property and property.

3) Principles of Land Buying and Selling

Land buying and selling is legal if it meets bright conditions and cash, this has consistently been held in jurisprudence regarding the sale and purchase of land. Bright means that the transitional transaction of land rights must be witnessed by a General Officer. Cash means that the sale and purchase of land is only valid if there is a payment in full and the delivery of land at the same time.

4) Principles for the Release of Basic Rights

The arising or loss of rights is not expired Adat law does not recognize the expired institution, but recognizes what is called a 'release of rights', meaning that if a piece of land is left, then the rights will recede and the peak will be released, as the physical relationship between the owner and the land concerned and vice versa.

5) Law of Indigenous Crime.

In the adat lawsystem, in fact no legal separation criminal law with other laws as in the western legal system, criminal imposition is solely carried out to determine the law (verklaring van recht) in the form of adat sanctions (traditional customs), to restore the violated adat law. The adat criminal law has been referred to in Article 5 paragraph 3 of Law No. 1 / Drt / 1951.

Some important jurisprudences concerning customary criminal law are:

(a) Act against the law.

For example PN Luwuk No. 27 / Pid / 1983, adjudicating cases of non-marital sex relations, the judge decided that the defendant violated the law which was held in a proud region, Central Sulawesi, based on the criminal element in article 5 paragraph 3 sub-b of the Draft 1 / Drt / 1951, whose elements are: The first element, an act that violates a living law; The second element, the violation has no equal in the Criminal Code; The third element, the act of violation still applies to the subjects and persons concerned.

Decision of PT Palu No. 6 / Pid / 1984 dated April 9, 1984 upheld the decision of the Luwuk District Court, adding that, to fulfill the sense of justice of the people, who considered the act a criminal act, the judge satisfied the defendant had committed a crime of intercourse with a woman outside of marriage. Supreme Court, with decision No. 666K / Pid / 1984 dated February 23, 1985, actions carried out by the accused were categorized as adultery according to customary law. The Supreme Court in its decision Number 3898K / Pdt / 1989, November 19, 1992, concerning similar customary violations in the Kafemenanu area, was filed civilly with a lawsuit, the bottom line: If two adults engage in sexual relations on the basis of liking which results in pregnant women, and the man is not responsible for the pregnancy, a customary sanction must be established in the form of payment of belis (fees or dowry) from the male side to the woman (known as Pualeu Manleu).

(b) The act violates the customary law of Logic Sanggraha in Bali.

In case Number 854K / Pid / 1983 dated October 30, 1984, According to the Supreme Court, a man who slept with a woman in one room and on a bed, is evidence that the man had intercourse with the woman. Based on the testimony of the victim witnesses and evidence from the other witnesses, the defendant had intercourse with the victim witness as referred to in the subsidiary charges.

(c) Decision of Mataram District Court NO. 051 / Pid.Rin / 1988 dated March 23, 198854.

The court considered it to have referred to a violation of the adat law of the Nambarayang or Nagmpesake delicacy. 
(d) MA-RI Number $481 \mathrm{~K} /$ Pid / 1986 dated August 31, 1989 from PN Ende Problatik women body organs 55, several times applied the provisions of article 378 of the Criminal Code, placing organs of Perebum as goods. The solution is applied in article 5 (3) b of Law Drt Number 1 of 1951 LN. Number 9 of 1950 dated January 13, 1951. In a similar case in the Medan District Court Number 571 / KS / 1980 dated March 5, 1980 the provisions of article 378 of the Criminal Code were implemented and strengthened by PT Number 144 / Pid / 1983 dated August 8, 1983. Goods were interpreted wide, so that the goods include services. Items inherent in one person (genitals) are also included in the understanding of goods, which in the Tapanuli language is known as "Bonda" which means "goods" which is nothing but "pubic". So when a girl surrenders her honor to a man,then it means that the girl handed over the items to the man. With this broad interpretation, the elements of goods in Article 378 of the Criminal Code have been fulfilled. In practice, many law enforcement officers (prosecutors) followed to ensnare a man who managed to fuck a girl who was going to be married, but eventually a man broke his promise, and the girl became a miserable victim for life.

\subsection{The Position of Islamic Law in Indonesia}

Related to economic activity, this time legal positive transformed toward the stem of Islamic law (sharia).[20] It can be said that in business activities such as corporate law, the financing law in banking, capital markets and insurance as well as contract law applies a dualism of the legal system, namely conventional and sharia. Related to the existence of Sharia principles in economic activity, the authors argue that it is precisely the institutions hu kum customary with respect to economic activity has much in common with the views of Islamic principles, such as prioritizing the principle of balance, the prohibition of exploitation without limit and sustainable development. $[21]^{2}$ Thus, at this time in addition to adat law, the principles of sharia became a source of formation of national law.

As an effort to foster and develop national law, Islamic law has provided a very large contribution, at least in terms of his soul. This statement is reinforced by several arguments. First, Law No. I of 1974 concerning Marriage. In Article 2 of this Law, it is written that marriage is legal if carried out according to the laws of each religion. While in article 63 states that, what is meant by the court in this Law is the Religious Court for those who are Muslim. Second, in in Law No.2 of 1989 concerning the National Education System, it is stated that in the framework of the whole human development is believing and fearing the Almighty God, noble character, having knowledge and skills, being spiritually healthy, having a solid and independent personality, having sense of community and national responsibility. Third, Law No. 7 of 1989 concerning the Religious Courts. Constitution This proves that the Religious Courts should be present, grow and develop on Indonesian soil. This matter prove the contribution of Muslims as a majority people.

Fourth, Compilation of Islamic Law (KHI), although no law was formed, but Presidential Instruction Number I of 1991. This compilation greatly helped the judges in deciding cases, especially in the Religious Courts. Fifth, PP No.28 of 1978 concerning the Representative Land Ownership, in addition to Law No.5 of 1960 as the principal arrangement of land issues in Indonesia. As the implementation was also issued Minister of Religion Regulation No. 1978 concerning Regulation No. PP. 28 of 1978. For the implementation, several regulations have been issued as follows: 1. Decree of the Minister of Religion No.73 of 1978 concerning Delegation of Authority to the Head of Regional Office of the Ministry of

\footnotetext{
${ }^{1}$ Mehmet Asutay, 2009, An Introduction to Islamic Moral Economy, Durham University: School of Government and International Affairs, p. 32-41.

${ }^{2}$ Suparman Usman, Hukum Islam, Asas-asas dan Pengantar Studi Hukum Islam dan Tata Hukum Indonesia, Jakarta: Gaya Mediapratama, 2001, p. 18
} 
Religion of the same level throughout Indonesia to appoint / dismiss the Head of KUA District as PAIW; 2.Instructions with the Minister of Religion and Minister of Home Affairs respectively 1 of 1978 concerning Implementation of Government Regulation No. 28 of 1978; 3. Minister of Religion Instruction No. 3 of 1979 concerning Implementation Guidelines for Minister of Religion Decree No. 73 of 1978 concerning Delegation of Authority to the Head of Regional Office of the Dep. Religion Province / equivalent to appoint / dismiss every Head of KUA Kec. as PPAIW; 4. Director General's Regulation on Islamic Military Affairs and Hajj Affairs No. D.II / 5 / Ed / 14/1980 concerning the Use of Stamp Duty with an attachment to the recording of the Letter of the Directorate General of Taxes No. S-629 / PJ.331 / 1080 concerning Provisions of the Minister of Finance concerning signs as referred to in Minister of Religion Regulation No. 1 Th. 1978 concerning PP No. 28 Th. 1977; 5.Minister of Religion Instruction No. 3 of 1979 concerning Implementation Guidelines for Minister of Religion Decree No. 73 of 1978 concerning Delegation of Authority to the Head of Regional Office of the Dep. Religion Province / equivalent to appoint / dismiss every Head of KUA Kec. as PPAIW; 4. Director General's Regulation on Islamic Military Affairs and Hajj Affairs No. D.II / 5 / Ed / 14/1980 concerning the Use of Stamp Duty with an attachment to the recording of the Letter of the Directorate General of Taxes No. S-629 / PJ.331 / 1080 concerning Provisions of the Minister of Finance concerning signs as referred to in Minister of Religion Regulation No. 1 Th. 1978 concerning PP No. 28 Th. 1977; 5.Minister of Religion Instruction No. 3 of 1979 concerning Implementation Guidelines for Minister of Religion Decree No. 73 of 1978 concerning Delegation of Authority to the Head of Regional Office of the Dep. Religion Province / equivalent to appoint / dismiss every Head of KUA Kec. as PPAIW; 4. Director General's Regulation on Islamic Military Affairs and Hajj Affairs No. D.II / 5 / Ed / 14/1980 concerning the Use of Stamp Duty with an attachment to the recording of the Letter of the Directorate General of Taxes No. S-629 / PJ.331 / 1080 concerning Provisions of the Minister of Finance concerning signs as referred to in Minister of Religion Regulation No. 1 Th. 1978 concerning PP No. 28 Th. 1977; 5.Religion Province / equivalent to appoint / dismiss every Head of KUA Kec. as PPAIW; 4. Director General's Regulation on Islamic Military Affairs and Hajj Affairs No. D.II / 5 / Ed / 14/1980 concerning the Use of Stamp Duty with an attachment to the recording of the Letter of the Directorate General of Taxes No. S-629 / PJ.331 / 1080 concerning Provisions of the Minister of Finance concerning signs as referred to in Minister of Religion Regulation No. 1 Th. 1978 concerning PP No. 28 Th. 1977; 5.Religion Province / equivalent to appoint / dismiss every Head of KUA Kec. as PPAIW; 4. Director General's Regulation on Islamic Military Affairs and Hajj Affairs No. D.II / 5 / Ed / 14/1980 concerning the Use of Stamp Duty with an attachment to the recording of the Letter of the Directorate General of Taxes No. S-629 / PJ.331 / 1080 concerning Provisions of the Minister of Finance concerning signs as referred to in Minister of Religion Regulation No. 1 Th. 1978 concerning PP No. 28 Th. 1977; 5. Minister of Home Affairs Regulation Number 6 of 1977 concerning Procedures for Land Registration concerning Property Representatives. 6. Letter of the Director General of Islamic Bimas and Hajj Affairs No.D.II / 5 / Ed / 07/1981 concerning Registration of Owned Land Representatives; 7. Letter of the Director General of Islamic Education and Hajj Affairs. D.II / 5 / Ed / 11 / 1981 concerning Guidelines for Filling in the numbers on the Perwakafan Land Ownership form.

Islamic law as a legal order that is guided and adhered to by the majority of the population and the people of Indonesia is a law that has lived in society, and is part of the teachings and beliefs of Islam that exist in the life of national law, and is an ingredient in its development.

The history of the journey of law in Indonesia, the presence of Islamic law in national law is a struggle for existence. Existence theory formulates the state of Indonesian national law, past, present, and future, asserting that Islamic law exists in Indonesia's national law, both written and unwritten. He is in various fields of legal life and legal practice. In the reform era a number of laws were born which could strengthen Islamic law, including: 


\section{(1) Law on the Implementation of Hajj.}

To support the efforts to carry out the effective, efficient and successful Hajj pilgrimage, the government issued Law No. 17 of 1999 concerning the Implementation of Hajj. Then followed up with the Minister of Religion Decree Number 224 of 1999 concerning the Implementation of Hajj and Umrah Services. Before that, during the Dutch colonial period the law on the implementation of the Hajj had once been implemented, namely the Hajj Ordinance (Pelgrims Ordonantie Staatsblad) in 1922 Number 698 including its amendments and additions and the 1938 Pelgrims Verodening.[22]

\section{(2) Zakat Management Law.}

The state guarantees its citizens to carry out their religious teachings, protect the poor and to realize the welfare of the Indonesian people as stated in Article 5 paragraph (1), Article 20 paragraph (1), Article 29 and Article 34 of the 1945 Constitution. the effort. Then Law No. 38 of 1999 was born regarding the Management of Zakat. To implement the Law, a Presidential Decree Number 8 of 2001 concerning the National Amil Zakat Agency emerged, which included the need for three components to carry out zakat management, namely the Executing Agency, the Advisory Council and the Supervisory Commission. Before the enactment of the law above, since the Dutch colonial period there had been legislation relating to zakat,namely Bijblad Number 2 of 1893 dated August 4, 1893 and Bijblad Number 6200 dated February 28, 1905. [23] In the 1422 H Nuzulul Qur'an Commemoration, President of the Republic of Indonesia Megawati Soekarnoputri has socialized the Government Regulation on $2.5 \%$ tax drought for taxpayers who have paid zakat through a Bank Account designated by the National Amil Zakat Agency. In fact, this has been done in the Director General of Taxes.

\section{(3) Waqf Law.}

In this law, waqf property is not restricted to immovable objects but also movable objects such as money, precious metals, securities, vehicles, intellectual property rights, rental rights and other movable objects in accordance with Shari'ah provisions and statutory regulations applicable laws. Even in this law, money waqf is arranged in a separate section. In Article 28 of this Law it is stated that authority: a. guiding Nazhir in managing and developing waqf property; $b$. conduct management and development of waqf assets nationally and internationally; c. give approval and or permission for changes in the allocation and status of property of waqf; d. dismiss and replace Nazhir; e. give approval for the exchange of waqf property; f. provide advice and consideration to the government in policy formulation in the field of representation.

\section{(4) Law on the Implementation of Privileges in Aceh and the Law on Special Autonomy in} Aceh.

Law No. 18 of 2001 on Special Autonomy Special Province of Aceh as Nanggroe Aceh Darussalam passed and enacted in Jakarta on August 9, 2001 (State Gazette of the Republic of Indonesia Year 2001 Number 114, T ambahan Gazette of the Republic of Indonesia Number 4134). The Government System and respect for special or special Regional Government units stipulated in the Law. Along with the emergence of the reform era and the aspirations of the people of Aceh, the Government gave special autonomy. In connection with that it is stipulated Law Number 18 of 2001 concerning Special Autonomy of the Special Province of Aceh as the Unitary State of the Republic of Indonesia according to the 1945 Constitution recognizes the Province of Nanggroe Aceh Darussalam. Seeing the social character and society of Aceh with a strong Islamic culture, and have given high fighting spirit during the struggle for the independence of the Indonesian state. So along with the emergence of the reform era and the aspirations of the people of Aceh. Government give special autonomy. In connection with the set of Law No. 18 of 2001 on Autonomy Special Provincial Istimewa Aceh Darussalam. 


\section{(5) Sharia banking.}

Although only in the Draft Sharia Banking Bill, but in Law Number 10 of 1998 concerning Banking strengthens the position of Islamic law as in articles 1, 6, 7, 8, 11 and 13. The article describes the dual banking system (conventional and sharia )

\section{(6) Law No. 3 of 2006 concerning Amendment to Law No. 7 of 1989 concerning the Religious Courts.}

Law number. 4 of 2004 explicitly regulates the transfer of organization, administration and finance from all judicial environments to the Supreme Court. Thus the organization, administration, finance of the judiciary in the Religious Courts which were previously under the Ministry of Religion based on Law No. 7 of 1989 adjusted to Law No. 3 of 2006. Law No. 4 of 2004 affirms the existence of a special court established in one of the judicial environments under the law. Therefore, the existence of a special court within the Religion Court is also regulated in Law No. 3 of 2006, namely the Islamic Sharia Courts in Nangroe Aceh Darussalam. The authority of the Religious Courts which was originally tasked with and authorized to examine, decide and settle first-degree cases between Muslim people in the fields of:a. Marriage, b. Inheritance, will and grant, c. Waqf and Sadaqah. Based on Law No. 3 of 2006 its authority was expanded in the field of shari'ah economics including: Syari'ah Bank, Syari'ah Insurance, Shari'ah Reinsurance and Shari'ah Intermediate Securities, Syari'ah Securities, Syari'ah Courts, Pension Funds Syari'ah Financial Institutions (DPLK), Sharia Business and Sharia Microfinance Institutions. Interestingly, in the old religious law, Law No. 7 of 1989 applies the principle of Choice of law (choice of law), namely in in the field of inheritance, parties who are Muslim before litigation may consider choosing what law is used in the distribution of inheritance. This provision in Law No. 3 of 2006 is no longer valid. So that Muslims who litigate their fellow Muslims in the field of inheritance are the authority of the Religious Courts.

\section{Conclusions}

Legal pluralism in Indonesia is the uniqueness of a legal system in the world. Whereas Adat law and Islamic law also have a significant influence on national law. During its development, the position of Adat law is under pressure from Islamic law due to national law, which is more accommodating to Islamic law because it has advantages in terms of the economy and the influence of the Indonesian population, predominantly Muslim. This condition is also due to the ambiguous position of customary law recognition in the national legal system. The current politics of law should give place to adat law because the national legal system also must absorb the living law not only in favor of the majority.

\section{References}

[1] De Cruz, Peter. Perbandingan Sistem Hukum Common Law, Civil Law, and Socialist Law, Nusa Media, Bandung, 2010, p. 46.

[2] Djuned T. 1992. Asas-asas Hukum Adat. Fakultas Hukum Unsyiah.

[3] H. Mustaghfirin, "Sistem Hukum Barat, Sistem Hukum Adat, Dan Sistem Hukum Islam Menuju Sebagai Sistem Hukum Nasional Sebuaha Ide Yang Harmoni”, Jurnal Dinamika Hukum, Volume 11, Edisi Khusus Februari (2011).

[4] Hoadley, Mason C, "The Leiden Legacy: Concepts of Law in Indonesia (Review)",Journal of Social Issues inSoutheast Asia, Vol. 21 No. 1 April (2006).

[5] Syamsudin, M., "Beban Masyarakat Adat Menghadapi Hukum Negara",Jurnal Hukum, Vol. 15 No. 3 Juli 2008. 
[6] Sahalessy J.,"Peran Latupati Sebagai Lembaga Hukum Adat Dalam Penylesaian Konflik Antar Negeri Di Kecamatan Leihitu Propinsi Maluku” p. 45, Jurnal Sasi, Vol. 17 No. 3 Juli-September (2011)

[7] Rosmidah, "Pengakuan Hukum Terhadap Hak Ulayat Masyarakat Hukum Adat Dan Hambatan Implementasinya Vol. 2 No. 2,", Inovatif: Jurnal Ilmu Hukum (2010)

[8] Supusesa Reimon, "Eksistensi Hukum Delik Adat dalam Perspektif Pembaharuan Hukum Pidana

Di Maluku Tengah”, , p. 1-186,.Jurnal Mimbar Hukum Vol. 24, No. 1 Februari (2012)

[9] Kusni Sulang, "Kemajemukan Hukum Adat Sebagai Rahmat”, p.1. e-Jurnal Toddpuli,20Februari (2011)

[10] Atmasasmita, Romli, 2010, Globalisasi Kejahatan Bisnis, , p. 190. Jakarta: Kencana Prenada Media Group

[11] Bushar Muhammad. 2002. Asas Asas Hukum Adat-Suatu Pengantar, Jakarta: Pradnya Paramita. p .47

[12] Desi Tamarasari, "Pendekatan Hukum Adat Dalam Menyelesaikan Konflik Masyarakat Pada Daerah Otonomi”, Jurnal Kriminologi Indonesia Vol. 2 No. 1 Januari 2002.

[13] Soepomo, 2003, Bab Bab Tentang Hukum Adat, Jakarta:Pradnya Paramita, p. 70.

[14] Dewi Ratna Winahyu Lestari, "Peranan Hukum Adat dalam Pembangunan Dan Pembangunan KUHP Nasional”, JurnalPerspektif Vol. X No. 3 Edisi Juli, Tahun 2005.

[15] Sulastriyono and Aristya, "Penerapan norma dan Asas-Asas Hukum Adat Dalam Praktik Peradilan Perdata", Jurnal Mimbar Hukum Vol. 24 No. 1 Februari 2012

[16] Asutay, Mehmet, 2009, An Introduction to Islamic Moral Economy, Durham University: School of Government and International Affairs, p. 32-41

[17] Usman, Suparman, Hukum Islam, Asas-asas dan Pengantar Studi Hukum Islam dan Tata Hukum Indonesia, Jakarta: Gaya Mediapratama, 2001, p. 18

[18] Muchsin, Masa Depan Hukum Islam di Indonesia, Jakarta: STIH Iblam, 2004, p. 41 